\title{
KUALITAS PELAYANAN PUBLIK DI KANTOR KECAMATAN KARANGGENENG KABUPATEN LAMONGAN
}

\author{
M. Yanto \\ Prodi Manajemen, Fakultas Ekonomi, Universitas Islam Lamongan \\ $\mathrm{Jl}$. Veteran No.53A Lamongan \\ Telp. ( 0322 ) 324706, Faks. ( 0322 ) 324706
}

Email:jpim@unisla.ac.id

\begin{abstract}
ABSTRAK
Penelitian ini bertujuan untuk mengetahui (1) kualitas pelayanan publik di Kantor Kecamatan Karanggeneng Kabupaten Lamongan, (2) Faktor pendukung dan penghambat pelayanan di Kantor Kecamatan Karanggeneng Kabupaten Lamongan.

Metode penelitian ini adalah penelitian deskriptif dengan pendekatan kualitatif. Penelitian deskriptif kualitatif merupakan penelitian yang bertujuan untuk menggambarkan dan mendeskripsikan peristiwa maupun fenomena yang terjadi di lapangan dan menyajikan data secara sistematis, faktual, dan akurat mengenai fakta-fakta atau fenomena yang terjadi di lapangan. Pengumpulan data dilakukan dengan teknik observasi dan dokumentasi. Peneliti menggunakan triangulasi sumber untuk mengecek keabsahan data penelitian. Analisis data dalam penelitian ini menggunakan tiga komponen yang terdiri dari reduksi data, penyajian data, dan penarikan kesimpulan.

Hasil penelitian ini menunjukan bahwa (1) Kualitas pelayanan publik di Kantor Kecamatan Karanggeneng Kabupaten Lamongan sudah diterapkan dimensi RATERReliability, Assurance, Tangibles, Emphaty, Responsiveness,beserta indikatornya. Namunada beberapa indikator yang belum berjalan sesuai dengan keinginan masyarakat, antara lain ketidaknyamanan tempat pelayanan termasuk sarana dan prasarana yang belum lengkap, belum ahlinya pegawai dalam menggunakan alat bantu pelayanan, dan kurang ramahnya pegawai dalam proses pelayanan. (2) Faktor penghambat pelaksanaan pelayanan publik di Kantor Kecamatan Karanggeneng Kabupaten Lamongan adalah kurangnya sumber daya pegawai dan masih kurangnya sarana prasarana. Sedangkan faktor pendukungnya adalah semangat yang diberikan pegawai satu sama lain, mengadakan rapat koordinasi atau semacam evaluasi setiap tiga bulan kemudian memberikan penanaman kesadaran melayani masyarakat dengan ikhlas dan sesuai dengan hati nurani. Faktor pendukung lain adalah adanya fasilitas berupa alat bantu untuk memudahkan proses pelayanan.
\end{abstract}

Kata Kunci : Kualitas Pelayanan Publik, pelayanan publik.

\section{PENDAHULUAN}

\section{Latar Belakang}

Pelayanan merupakan tugas utama yang hakiki dari sosok aparatur, sebagai abdi negara dan abdi masyarakat. Tugas ini telah jelas digariskan dalam pembukaan UUD 1945 alinea keempat, yang meliputi 4 (empat) aspek pelayanan pokok aparatur terhadap masyarakat, yaitu melindungi segenap bangsa Indonesia dan seluruh tumpah darah Indonesia, memajukan kesejahteraan umum, mencerdaskan kehidupan bangsa dan melaksanakan ketertiban dunia yang berdasarkan kemerdekaan, perdamaian abadi dan keadilan sosial selain itu diperjelas lagi dalam Keputusan Menteri Pendayagunaan Aparatur Negara No. 63 tahun 2003 yang menguraikan pedoman umum penyelenggaraan pelayanan publik.

Pelayanan publik yang berkualitas atau yang biasa disebut dengan pelayanan prima merupakan pelayanan terbaik yang memenuhi standar kualitas pelayanan. Standar Pelayanan adalah tolok ukur yang dipergunakan sebagai pedoman penyelenggaraan pelayanan dan acuan penilaian kualitas pelayanan sebagai kewajiban dan janji penyelenggara pelayanan kepada masyarakat dalam rangka pelayanan

Jurnal Penelitian Ilmu Manajemen 
yang berkualitas, cepat, mudah, terjangkau, dan terukur. Menurut Peraturan Menteri Pendayagunaan Aparatur Negara Dan Reformasi Birokrasi Republik Indonesia Nomor 15 Tahun 2014, komponen standar pelayanan yang terkait dengan proses penyampaian pelayanan meliputi Persyaratan, prosedur, jangka waktu pelayanan, biaya/tarif, produk pelayanan, dan penanganan pengaduan. Jika suatu Instansi pemerintah dan lembaga lainnya mampu menerapkan standarkualitas tersebut maka sudah dapat dikatakan bahwa Instansi pemerintahdan lembaga tersebut telah memberikan kualitas pelayanan yang baik.

Menurut Keputusan Menteri Pendayagunaan Aparatur Negara Nomor 63 tahun 2004 Tentang Pedoman Umum Penyusunan Indeks Kepuasan Masyarakat Unit Pelayanan Instansi Pemerintah, Pelayanan publik adalah segala kegiatan pelayanan yang dilaksanakan oleh penyelenggara pelayanan publik sebagai upaya pemenuhan kebutuhan penerima pelayanan, maupun dalam rangka pelaksanaan ketentuan peraturan perundangundangan. Penyelenggara pelayanan publik adalah petugas pelayanan publik baik Pemerintah Daerah maupun Badan Usaha Milik Daerah yang menyelenggarakan pelayanan publik. Sedangkan penerima layanan publik adalah perseorangan atau kelompok masyarakat dan badan hukum yang memiliki hak dan kewajiban terhadap suatu pelayanan publik.

\section{Pelayanan Publik merupakan segala} kegiatan dalam rangka pemenuhan kebutuhan dasar sesuai dengan hak-hak dasar setiap warga negara atau penduduk atas suatu barang, jasa dan pelayanan administrasi yang disediakan oleh penyelenggara pelayanan yang terkait dengan kepentingan publik. Contoh pelayanan publik dalam bentuk pelayanan administrasi yaitu pembuatan KTP (Kartu Tanda Penduduk) dan SKCK (Surat Keterangan Catatan Kepolisian), pelayanan dalam bentuk jasa misalnya kantor pos dan bank. Sedangkan pelayanan dalam bentuk barang seperti pembayaran pajak yang digunakan untuk pembangunan infrastuktur negara seperti jembatan dan jalan tol.

Pelayanan publik yang diselenggarakan oleh instansi pemerintah belum dapat memenuhi kualitas yang diharapkan masyarakat. Hal ini ditandai dengan masih adanya berbagai keluhan masyarakat mengenai diskriminasi pelayanan. Sebagai contoh adanya masyarakat yang dipersulit ketika mengurus KTP (Kartu Tanda Penduduk) di instansi pemerintah seperti dikenakan biaya ekstra untuk mendapatkan pelayanan yang lebih cepat. Selain itu keluhan lain yang diungkapkan pengguna layanan yaitu adanya ketidakpastian waktu sehingga mengakibatkan rendahnya kualitas pelayanan. Ketidakpastian waktu dapat menimbulkan citra yang kurang baik terhadap Instansi pemerintah tersebut. Mengingat fungsi utama pemerintah adalah melayani masyarakat, maka pemerintah perlu terus berupaya meningkatkan kualitas pelayanan.

Berdasarkan data atau informasi yang diperoleh dari merdeka.com (http://www.merdeka.com/peristiwa/laporanpengaduan-pelayanan-publik-ke-ombudsmanmeningkat-350.html),jumlah laporan pengaduanmasyarakat terkait penyelenggaraan 
pelayanan publik terus meningkat sebesar 350\%, ujar Ketua Ombudsman RI Danang Girindrawardana. Peningkatan pengaduan tersebut tidak hanya berkisar pada pengaduan yang bersifat insidental pelayanan publik saja. Keluhan ini juga meningkat drastis pada masalah-masalah sistemik kebijakan-kebijakan yang mengakibatkan terjadinya penundaan berlarut, pengutan liar, ketidakpastian prosedur pelayanan dan konflik kepentingan. Banyaknya pengaduan yang masuk tersebut perlu segera disikapi oleh Instansi yang bersangkutan.

Berdasarkan temuan observasi tersebut menyatakan bahwa Implementasi pelayanan publik baik oleh pemerintah pusat maupun daerah masih memprihatinkan dapat dilihat daridata Ombudsman Republik Indonesia yang menyatakan bahwa rata-rata implementasi tersebut berada di bawah 30 persen. Tingkat kementerian 22,2 persen, lembaga negara dan pemerintahan 27 persen dan pemerintah daerah 10,5 persen. Semakin rendah implementasi pelayanan publik, dapat memicu meningkatnya potensi pungutan liar (pungli dan korupsi) serta dapat dinilai bahwa Instansi pelayanan publik telah mengabaikan Undang-undang Pelayanan Publik dan membiarkan atau menumbuhkan potensi terjadinya pungli dan korupsi di sektor pelayanan publik.

\section{Tujuan Penelitian}

Dalam penelitian yang dilakukan penulis mempunyai beberapa tujuan yakni:

1. Untuk mengetahui bagaimana kualitas pelayanan di kantor kecamatan karanggeneng kabupaten Lamongan.
2. Untuk mengetahui apa saja faktor pendukung dan penghambat pelayanan di kantor kecamatan karanggeneng.

\section{METODE PENELITIAN}

\section{Desain Penelitian}

Penelitian ini merupakan penelitian deskriptif dengan pendekatan kualitatif. Penelitian deskriptif kualitatif merupakan penelitian yang bertujuan untuk menggambarkan dan mendeskripsikan peristiwa maupun fenomena yang terjadi di lapangan dan menyajikan data secara sistematis, faktual, dan akurat mengenai faktafakta atau fenomena-fenomena yang terjadi di lapangan. Penelitian deskriptif kualitatif bertujuan untuk menggambarkan, melukiskan, menerangkan, menjelaskan dan menjawab secara lebih rinci permasalahan yang akan diteliti dengan mempelajari semaksimal mungkin seorang individu, suatu kelompok atau suatu kejadian. Dalam penelitian kualitatif manusia merupakan instrumen penelitian dan hasil penulisannya berupa kata-kata atau pernyataan yang sesuai dengan keadaan sebenarnya.

\section{Definisi Operasional}

Kualitas pelayanan publik merupakan usaha untuk memenuhi segala sesuatu yang berhubungan dengan produksi, jasa, manusia, proses, lingkungan, dan yang akan menjadi kebutuhan serta keinginan konsumen baik itu berupa barang dan jasa yang diharapkan dapat memenuhi harapan dan kepuasan masyarakat sebagai pengguna layanan. Terdapat lima dimensi dalam mengukur kualitas pelayanan, yaitu : Tangibel (Berwujud), Reliability (Kehandalan), Responsiviness (Ketanggapan), Assurance (Jaminan), Emphaty (Empati). 


\section{Informan Penelitian}

Teknik penentuan informan dalam penelitian ini menggunakan teknik purposive sampling dan snowball sampling sehingga terdapat informan kunci dan informan pendukung. Purposive sampling adalah adalah teknik penentuan informan dengan pertimbangan pada kemampuan informan untuk memberikan informasi selengkap mungkin kepada penulis. Sedangkan snowball sampling adalah teknik penentuan informan dengan mula-mula menentukan informan dalam jumlah kecil, kemudian membesar jika informan yang telah dipilih belum memberikan informasi atau data yang dibutuhkan oleh peneliti. Maka diambil dari masyarakat sebagai responden karena pelaksanaan pelayanan publik melibatkan peran pegawai dan masyarakat sebagai informan di Kantor Kecamatan Karanggeneng.

\section{Teknik Pengumpulan Data}

Dalam penelitian ini pengumpulan data dilakukan dengan menggunakan teknikObservasi. Observasi merupakan teknik pengumpulan data yang digunakan dalam penelitian untuk melakukan pengamatan secara langsung di lapangan. Teknik ini digunakan untuk mengamati pelaksanaan pelayanan publik yang terjadi antara pegawai dan masyarakat sebagai pengguna layanan di Kantor Kecamatan Karanggeneng. Dalam penelitian ini dilakukan pengamatan langsung dalam pelaksanaan pelayanan publik.

\section{HASIL PENELITIAN DAN PEMBAHASAN}

Untuk mengetahui kualitas pelayanan publik di Kantor Kecamatan Karanggeneng saat ini, peneliti menggunakan lima dimensi kualitas pelayanan publik yang dikemukakan oleh Zeithaml dkk dalam Hardiansyah, yaitu Tangible

(Berwujud),

Reliability

(Kehandalan), Responsiviness (Ketanggapan), Assurance (Jaminan), dan Emphaty (Empati). Selain itu peneliti juga meneliti apa yang menjadi faktor pendukung dan penghambat kualitas pelayanan publik di kantor Kecamatan Karanggeneng.

\section{Dimensi Tangible (Berwujud)}

Dimensi Tangible (berwujud) merupakan penampilan fasilitas fisik, peralatan, personal, dan media komunikasi dalam pelayanan. Jika dimensi ini dirasakan oleh masyarakat sebagai pengguna layanan sudah baik maka masyarakat akan menilai baik dan merasakan kepuasan terhadap pelayanan yang diberikan pegawai pelayanan Kecamatan Karanggeneng namun sebaliknya jika dimensi ini dirasakan oleh masyarakat buruk, maka masyarakat akan menilai buruk dan tidak akan merasa puas terhadap pelayanan yang diberikan pegawai pelayanan. Untuk mengukur dimensi Tangible dalam upaya mengetahui kualitas pelayanan publik di Kantor Kecamatan Karanggeneng dapat diukur melalui indikator sebagai berikut :

a. Penampilan pegawai dalam melayani pengguna layanan

Penampilan pegawai pelayanan sangat mempengaruhikualitas layanan yang diberikan. Berkaitan dengan penampilan pegawai pelayanan, di Kantor Kecamatan Karanggeneg pegawai layanan sudah berpenampilan rapi dan menggunakan seragam sesuai 
dengan ketentuan yang sudah ditetapkan."Penampilan itu sangat berpengaruh besar dalam proses pelayanan karena penampilan merupakan salah satu unsur yang nanti mendukung untuk memberikan pelayanan, sikap dan penampilan pegawai merupakan kesan pertama bagi pengguna layanan yang datang. Jika penampilan pegawai tidak menarik, maka pengguna layanan juga tidak akan tertarik dengan kualitas pegawai pelayanan tersebut. Selain itu, penampilan pegawai pelayanan di Kantor Kecamatan Karanggeneng sudah mengenakan seragam sesuai dengan ketentuan yang telah ditetapkan oleh pemerintah kabupaten yaitu seragam pegawai negeri"

b. Kenyamanan tempat melakukan pelayanan

Kenyamanan tempat dalam proses pelayanan sangat penting bagi pengguna layanan. Selain itu tempat pelayanan juga sangat mempengaruhi kualitas pelayanan.Kecamatan sebagai penyedia layanan publik harus memberikan kenyamanan tempat bagi pengguna layanan yang datang, dari menyediakan tempat yang cukup agar pengguna layanan tidak merasakan sempit di dalam ruangan, kemudian menyediakan tempat duduk yang disesuaikan dengan ruangan yang ada. Selain tempat duduk, pendingin ruangan seperti $A C$ juga dibutuhkan untuk kenyamanan pengguna layanan. Jika hari sudah mulai siang, maka biasanya di dalam ruangan akan menjadi lebih panas, apalagi banyak orang yang mengantri untuk mendapatkan pelayanan."Kenyamanan tempat pelayanan sangat mempengaruhi kualitas dari pelayanan karena jika masyarakat harus menunggu dengan suasana ruangan yang tidak nyaman maka masyarakat pun akan menjadi tidak nyaman. Jika pengguna layanan harus mengantri dengan suasana nyaman dan bersih maka masyarakat akan bersediauntuk bersabar. Tetapi sebaliknya jika proses pelayanan lama dan tempat pelayanan kurang nyaman dan tidak bersih maka masyarakat tidak akan merasa nyaman. Oleh karena itu, masih terdapat keluhan dari masyarakat sebagai pengguna layanan terkait kenyamanan tempat pelayanan. Masyarakat menyampaikan bahwa jika sudah siang hari ruangan menjadi panas walaupun sudah ada kipas angin".

c. Kedisiplinan pegawai dalam melakukan proses pelayanan

Disiplin kerja sangat dibutuhkan oleh setiap pegawai dalam melaksanakan pelayanan. Disiplin menjadi persyaratan bagi pembentukan sikap, perilaku, dan tata kehidupan yang akan membentuk kepribadian pegawai yang penuh tanggng jawab dalam bekerja, dengan begitu akan menciptakan suasana kerja yang kondusif dan mendukung usaha pencapaian tujuan. Apalagi dalam prosespelayanan, petugas harus disiplin 
dalam segi waktu maupun disiplin kerja, khususnya dalam mengerjakan keperluan pengguna layanan. Pegawai pelayanan harus mementingkan keperluan pengguna layanan di atas kepentingan pribadinya karena pekerjaan pelayanan merupakan pekerjaan yang mengedepankan kepentingan umum, dengan kata lain kepentingan pengguna layanan harus diprioritaskan oleh pegawai layanan.

\section{Dimensi Reliability (Kehandalan)}

Dimensi Reliability (Kehandalan) merupakan kemampuan unit pelayanan dalam memberikan pelayanan yang dijanjikan dengan segera dan memuaskan. Dimensi Reliability ini juga merupakan kemampuan penyedia layanan untuk memberikan pelayanan secara tepat waktu dan konsisten. Kehandalan dapat diartikan mengerjakan dengan benar sesuai dengan prosedur kerja, standar pelayanan dan waktu yang telah dijanjikan. Pemenuhan pelayanan yang tepat dan memuaskan meliputi ketepatan waktu, kecakapan dalam memberikan layanan serta kecakapan dalam menanggapi keluhan jika ada keluhan yang masuk dari pelanggan serta pemberian pelayanan secara wajar dan akurat. Untuk mengukur dimensi Reliability dalam upaya mengetahui kualitas pelayanan publik di Kantor Kecamatan Karanggeneng dapat diukur melalui indikator sebagai berikut:

a. Kecermatan pegawai dalam melayani pengguna layanan

Kecermatan atau ketelitian pegawai dalam melayanipengguna layanan sangat penting bagi proses pelayanan. Jika pegawai tidak cermat dalam melayani masyarakat maka akan terjadi kesalahan dan menimbulkan pekerjaan baru. Sebagai contoh ketika pegawai salah ketik dalam penulisan nama pada KTP, maka pengguna layanan harusmengurus kembali nama yang salah tersebut. Dari ketidakcermatan tersebut akan menimbulkan pekerjaan baru yang seharusnya tidak perlu dilakukan oleh pegawai, serta akanmenimbulkan penilaian yang kurang baik oleh pengguna layanan terhadap kualitas pelayanan yang diberikan. Maka dari itu pegawai harus cermat dalam mengerjakan tanggung jawab tugas khususnya yang berkaitan dengan pelayanan agar tercipta pelayanan yang baik dan masyarakat akan menilai baik."Pegawai disini sudah cermat. Selama pengamatan kepada pegawai mengurus keperluan belum pernah menemukan kesalahan yang dilakukan oleh pegawai pelayanan."Selama ini dalam melakukan proses pelayanan, pegawai selalu berpedoman pada tupoksi dari Kabupaten, sehingga jarang terjadi kesalahan yang dilakukan oleh pegawai layanan. Misalnya untuk mengurus mutasi penduduk, pegawai memberi tahu syarat-syarat yang harus dilengkapi oleh pengguna layanan. 
b. Memiliki Standar Pelayanan yang jelas

Memiliki Standar Pelayanan Publik yang jelas memang penting untuk pedoman pegawai dalam melayani pengguna layanan dalam proses pelayanan karena dengan berpatokan kepada Standar Pelayanan, proses pelayanan dapat berjalan dengan baik guna mencapai tujuan pelayanan khususnya di Kecamatan Karanggeneng.Standar Pelayanan Publik Pada Kecamatan. Standar ini meliputi prosedur pelayanan, waktu pelayanan, biaya pelayanan, produk pelayanan, sarana prasarana, dan kompetensi petugas pelayanan.namun masyarakat sebagai pengguna layanan tidak semuanya mengetahui standar pelayanan publik di kantor Kecamatan Karanggeneng.

c. Keahlian pegawai dalam menggunakan alat bantu dalam proses pelayanan

Selain kemampuan, keahlian dalam menggunakan alat bantu juga perlu dimiliki oleh pegawai layanan dalam melayani masyarakat. Terlihat jika pelayanan ramai dengan banyaknya pengguna layanan yang datang, pegawai yang ahli dalam menggunakan alat bantu dalam proses pelayanan seperti kamera untuk pembuatan KTP, komputer dan perangkatnya hanya satu atau dua yang ahli dalam menguasai alat bantu tersebut. "Pegawai pelayanan di sini belum mempunyai keahlian untuk menggunakan alat bantu dalam proses pelayanan karena kami bukan dari pegawai pelayanan yang tetap. Kami bertugas di sini karena dibagian pelayanan Kecamatan Karanggeneng belum mempunyai pegawai pelayanan tetap yang seharusnya sudah ahli dalam menggunakan alat bantu dalam proses pelayanan. Sebagian dari kami adalah seksi pemerintahan yang ditugaskan kantor Catatan Sipil untuk membantu pelayanan di sini."

\section{Dimensi Responsiviness (Ketanggapan)}

Dimensi Responsiviness (Ketanggapan) yaitu sikap tanggap pegawai dalam memberikan pelayanan yang dibutuhkan dan dapat menyelesaikan pelayanan dengan cepat sesuai jangka waktu yang telah dijanjikan. Kecepatan pelayanan yang diberikan merupakan sikap tanggap dari petugas dalam pemberian pelayanan yang dibutuhkan. Sikap tanggap ini berkaitan dengan akal dan cara berfikir pegawai yang ditunjukkan pada pelanggan. Untuk mengukur dimensi Responsiviness dalam upaya mengetahui kualitas pelayananpublik di Kantor Kecamatan Karanggeneng dapat diukur melalui indikator sebagai berikut :

a. Merespon setiap pengguna layanan yang ingin mendapatkan pelayanan

$$
\text { Pegawai layanan wajib }
$$
merespon pengguna layanan yang datang. Pengguna layanan akan merasa dihargai oleh pegawai layanan ketika pegawai layanan dapat memberikan respon yang baik. Merespon pengguna layanan dapat 
menimbulkan efek positif bagi kualitas pelayanan publik di kantor Kecamatan Karanggeneng. Pegawai merespon dan tanggap dengan para pengguna layanan yang ingin mendapatkan pelayanan ini dibuktikan ketika pengguna layanan yang sudah selesai mendapatkan pelayanan, pegawai langsung memanggil antrian selanjutnya dan bertanya apa keperluan yang diperlukan.Pengguna layanan pasti akan senang jika pegawai di kantor pelayanan respon atau tanggap terhadap keperluan pengguna layanan. Ini akan menjadi penilaian yang baik bagi penyedia layanan.

b. Pegawai melakukan pelayanan dengan cepat

Pengguna layanan akan merasa senang ketika pegawai layanan melakukan proses pelayanan dengan cepat dan tepat. Tepat dapat diartikan pegawai memberikan layanan sesuai dengan keperluan pengguna layanan. Pelayanan yang tepat merupakan kesesuaian antara pelayanan yang diberikan dengan keperluan pengguna layanan sehingga keperluan yang dihadapi pengguna layanan dapat terselesaikan dengan baik dan pada akhirnya kepuasan masyarakat tercapai. Contohnya saat pengguna layanan yang akan melegalisir $\mathrm{KK}$, ketika pegawai memanggil pengguna layanan sesuai antriannya, kemudian pegawai langsung memberikan pelayanan dengan cepat, sehingga pengguna puas dengan pelayanan yang diberikan. Namun tidak semua pegawai dapat melayani dengan cepat. Semua itu tergantung ada atau tidaknya pegawai yang ada di ruang pelayanan. Jika pegawai hanya ada satu atau dua sedangkan yang mengantri ada banyak maka kemungkinan untuk melayani dengan cepat akan sedikit.Pelayanan yang cepat dan tepat merupakan hal penting yang harus dilakukan sebagai bentuk responsiviness terhadap pengguna layanan, akan tetapi selain cepat pelayanan juga harus dilakukan dengan tepat. Jika pegawai sudah memberikan pelayanan dengan cepat dan teliti maka pegawai layanan sudah menjalankan tugas dengan profesional sehingga pengguna layanan akan merasa senang.

c. Semua keluhan pelanggan direspon oleh pegawai

Keluhan akan terjadi jika pegawai layanan tidak melaksanakan proses pelayanan dengan baik. Kantor Kecamatan Karanggeneng sebagai penyedia layanan menyediakan sarana untuk menyampaikan keluhan jika ada pengguna layanan yang mempunyai keluhan terkait proses pelayanan. Seperti yang peneliti lihat Kecamatan Karanggeneng menyediakan kotak saran dan website untuk memberikan komentar atau memberikan keluhan terkait pelayanan yang ada di Kantor Kecamatan Karanggeneng. Biasanya 
ketika ada keluhan masuk secara langsung pegawai langsung menanggapi dan mengucapkan terima kasih. Selanjutnya keluhan akan disampaikan dan dibahas bersama pada rapat rutin 3 bulan yang telah diagendakan.

\section{Dimensi Assurance (Jaminan)}

Dimensi Assurance (Jaminan) yaitu mencakup pengetahuan, kemampuan, kesopanan dan sifat dapat dipercaya yang dimiliki pegawai, bebas dari bahaya, resiko, dan keragu-raguan. Jaminan adalah upaya perlindungan yang disajikan untuk masyarakat bagi warganya tehadap resiko yang apabila resiko itu terjadi akan dapat mengakibatkan gangguan dalam struktur kehidupan yang normal. Untuk mengukur dimensi Assurance dalam upaya mengetahui kualitas pelayanan publik diKantor Kecamatan Karanggeneng dapat diukur melalui indikator sebagai berikut :

a. Petugas memberikan jaminan tepat waktu dalam pelayanan

Pegawai di Kantor Kecamatan Karanggeneng memberikan jaminan tepat waktu dalam pelayanan saat itu juga apabila bisa diselesaikan pegawai mengusahakan tepat waktu. Jika memang tidak bisa diselesaikan hari itu juga seperti contoh membuat KTP yang tidak bisa langsung selesai hari itu,pegawai memberikan jaminan waktu dan memberikan bukti pengambilan agar ketika sudah selesai jangka waktunya langsung bisa diambil dengan menggunakan bukti pengambilan yang sudah diberikan kepada pelanggan tersebut."Standar waktu yang diberikan yaitu tiga hari namun pada kenyataannya waktu yang diperlukan untuk menyelesaikan pembuatan KTP mencapai enam sampai tujuh hari. Keterlambatan ini dikarenakan bahan dasar untuk membuat KTP, seperti kartu itu sendiri harus menunggu pengiriman dari kantor pusat yang membutuhkan waktu yang tidak sebentar. Itulah faktor utama yang menyebabkan jangka waktu pembuatan KTP tidak sesuai dengan jangka waktu yang seharusnya yaitu tiga hari."

b. Petugas memberikan jaminan biaya dalam pelayanan

Dalam mengurus keperluan di Kecamatan, tidak semuamengeluarkan biaya untuk mengurusnya. Tergantung jenis pelayanannya. KTP, KK, dan suratsurat lainnya itu gratis kecuali IMB dan Ijin gangguan. Ketika mengamati, peneliti memang tidak melihat pengguna layanan memberikan uang kepada pegawai layanan kecuali pengguna layanan mengurus IMB dan ijin gangguan.Jaminan kepastian biaya sudah ada di PeraturanBupati mengenai tentang Standar Pelayanan Publik di Kecamatan.

\section{DimensiEmphaty (Empati)}

Dimensi Emphaty (Empati) meliputi kemudahan dalam melakukan hubungan, komunikasi yang baik dan memahamikebutuhan pengguna layanan. Empati adalah perhatian yang 
dilaksanakan secara pribadi atau individu terhadap pengguna layanan dengan menempatkan dirinya pada situasi sebagai pengguna layanan. Untuk mengukur dimensi Emphaty (Empati) dalam upaya mengetahui kualitas pelayanan publik di Kantor Kecamatan Karanggeneng dapat diukur melalui indikator sebagai berikut :

a. Mendahulukan Kepentingan pengguna layanan

Pengguna layanan dalam proses pelayanan merupakan prioritas dalam pelayanan. Apapun keperluan pengguna layanan terkait pelayanan di Kecamatan harus pendapat prioritas utama dan harus sesuai dengan apa yang diperlukan oleh pengguna layanan. Namun ketika peneliti mengamati tidak semua pegawai mendahulukan kepentingan pengguna layanan. Terlihat ketika masih ada pengguna layanan yang mengantri namun ada pegawai yang memiih untuk mementingkan urusan pribadinya seperti menjemput anak ke sekolah.Mendahulukan kepentingan pengguna layanan memang penting karena pengguna layanan merupakan prioritas pegawai layanan. Jika pengguna layanan tidak merasa didahulukan akan timbul keluhan dan akan memberikan citra yang buruk bagi bagian pelayanan.

b. Petugas melayani dengan ramah dan sopan santun

Keramahan pegawai pelayanan sangat diperlukan dalam proses pelayanan. Jika pegawai pelayanan ramah maka akan memberikan penilaian yang baik dari pengguna layanan, karena pada dasarnya semua orang akan menyukai tempat pelayanan yang didalamnya banyak terdapat orang yang ramah. Orang yang ramah berati orang yang tanggap dengan keperluan orang lain. Selain ramah, sikap sopan santun juga sangat diperlukan oleh pegawai layanan untuk melayani pengguna layanan.Keramahan dan sikap sopan santun pegawai pelayanan sangat diperlukan dalam proses pelayanan. Jika pegawai pelayanan ramah dan sopan santun maka akan memberikanpenilaian yang baik dari pengguna layanan, karena pada dasarnya semua orang akan menyukai tempat pelayanan yang didalamnya banyak terdapat orang yang ramah dan sopan santun. Orang yang ramah berati orang yang tanggap dengan keperluan orang lain. Namun ketika peneliti mengamati, belum semua pegawai memberikan keramahan kepada pengguna layanan karena ada beberapa pegawai yang mengobrol dengan pegawai lain ketika melayani pengguna layanan.

"Pegawai di sini ya ada yang ramah dan sopan tapi juga ada yang kurang ramah, mungkin sedang ada sesuatu, jadi hanya menanyakan keperluan tanpa menyapa terlebih dahulu”.Keramahan dan sikap sopan santun memang sangat penting dimiliki oleh pegawai pelayanan 
dalam prosespelayanan melayani pengguna layanan agar pengguna layanan merasa puas terhadap pelayanan yang diberikan.

c. Pegawai melayani dengan tidak diskriminatif (Membeda bedakan)

Dalam proses pelayanan, tidak hanya keramahan dan sikap sopan santun, tetapi sikap tidak membedabedakan juga sangat perlu untuk diterapkan. Sikap tidak membedabedakan maksudnya, ketika melayani pegawai tidak mendahulukan pengguna layanan yang sudah kenal saja misalnya keluarga atau teman dekat. Semua harus dilayani dengan sama dan harus sesuai nomor antrian.Sikap tidak membeda-bedakan dalam melayani masyarakat ini berarti pegawai layanan sudah melakukan pelayanan dengan profesional dan sesuai dengan standar pelayanan publik.

Instansi pemerintah daerah seperti kecamatan merupakan salah satu contoh instansi pemerintah yang melaksanakan pelayanan publik.Kecamatan sebagai penyedia layanan publik mempunyai tugas pokokmembantu Bupati dalam penyelenggaraan pemerintahan, pembangunan dankemasyarakatan dalam wilayah kecamatan serta meningkatkan efektivitaspelayanan publik dalam rangka penyelenggaraan pemerintahan yang baik/good governance) serta peningkatan kualitas pelayanan dalam bentuk jasaatau perijinan melalui transparasi dan standarisasi pelayanan. Adapun tugaslain dari kecamatan yaitu melayani dalam hal pembuatan Kartu TandaPenduduk (KTP), akta kelahiran, surat nikah, sertifikat tanah IjinMendirikan Bangunan (IMB), keterangan pindah, pertanahan, ijin tebangkayu rakyat, Surat Keterangan Catatan Kepolisian (SKCK), ijin keramaian,legalisasi surat-surat, dan program keluarga harapan.

Pelayanan yang baik kepada masyarakat harus didukung oleh pegawai-pegawai yang handal, berkompeten, mampu memahami serta dapat melaksanakan tugas pokok dan fungsinya sesuai dengan bidang tanggung jawab yang dibebankan kepadanya. Selain itu, mereka tentu harus memiliki komitmen dan tanggung jawab moral terhadap masyarakat. Masyarakat tentunya ingin mendapatkan kualitas pelayanan yang baik dari pemerintah. Pelayanan yang berkualitas atau yang biasa disebut dengan pelayanan prima merupakan pelayanan terbaik yang memenuhi standar kualitas pelayanan.Berdasarkan pra observasi yang dilakukan penulis pada pertengahan bulan Juni di Kantor Kecamatan Karanggeneng Kabupaten Lamongan, Penulis menemukan masalah terkait pelayanan publik. Masalah terkait pelayanan publik 
tersebut yaitu mengenai jangka waktu pelayanan,sebagai contoh ketika masyarakat mengurus Kartu Tanda Penduduk (KTP). Masyarakatmenyampaikan proses pembuatan KTP tidak sesuai dengan jangka waktuyang seharusnya yaitu tiga hari. Menurut Nara sumber Kepala bagianumum yang memberikan konfirmasi, "Standar waktu yang diberikan yaitutiga (3) hari" namun pada kenyataannya waktu yang diperlukan untukmenyelesaikan pembuatan KTP mencapai enam sampai tujuh hari yangdikarenakan bahan dasar untuk membuat KTP, seperti kartu KTP harusmenunggu pengiriman dari kantor pusat yang membutuhkan waktu. Itulahfaktor utama yang menyebabkan jangka waktu pembuatan KTP tidak sesuaidengan jangka waktu yang seharusnya yaitu tiga hari”.

Permasalahan kedua yaitu mengenai ketiadaan petugas di loket pelayanan Kecamatan Karanggeneng memiliki empat loket pelayanan umum, namun hanya terdapat dua pegawai dari bagian pemerintahan yang bertugas di empat loket pelayanan tersebut sehingga petugas harus membagi tugasnya. Ketiadaan petugas ini menyebabkan pengguna layanan harus menunggu dan bahkan pelayanannya dilakukan oleh pegawai yang lain. Selanjutnya mengenai ketiadaan petugas di meja buku tamu.
Peneliti sudah beberapa kali datang ke Kecamatan Karanggeneng, di sana tersedia meja untuk menulis buku tamu namun penulis tidak menemukan petugas yang menjaga meja tersebut. Sedangkan selain menjaga buku tamu, petugas mempunyai tugas untuk memberi tahu alur atau proses keperluan pengguna layanan.

Masalah ketiga, mengenai keramahan pegawai di Kecamatan kepada pengguna layanan yang datang. Ketidakramahan tersebut terlihat ketika pegawai yang tidak memberikan senyum kepada pengguna layanan, petugas, yang mengobrol dengan petugas lain yang membicarakan permasalahanyang tidak berkaitan dengan pelayanan yang diberikan sehingga masyarakatyang sedang menerima layanan tidak dilayani dengan baik. Selain itupenulis menemukan adanya respon pegawai yang tidak tanggap denganmasyarakat yang ingin melakukan pelayanan dan belum mengerti mengenaiprosedur pelayanan. sikap tidak tanggap sangat menganggu kualitaspelayanan yang di rasakan oleh masyarakat yang datang dan inginmendapatkan pelayanan yang baik.

Masalah selanjutnya, mengenai sarana yang masih kurang, misalnya filing cabinet yang berfungsi untuk menyimpan berkas dan 
memudahkanpegawai dalam mencari berkas namun didapati berkas yang disimpan dalam filing cabinet penataannya kurang rapi dan tidak ditemukan aturan dalampenyimpanan, sehingga ketika pegawai membutuhkan berkas/data tersebut pegawai mengalami kesulitan dalam menemukan berkas yang akan dibutuhkan. Sarana dan prasarana yang baik dibutuhkan agar masyarakat merasa lebih puas dengan pelayanan yang diberikan.

Masalah yang terakhir yaitu mengenai jumlah pegawai di Kecamatan Karanggeneng yang masih kurang dan dapat dilihat di tabel berikut.

\section{Tabel Jumlah pegawai di Kecamatan}

\section{Karanggeneng}

\begin{tabular}{|l|c|}
\hline \multicolumn{1}{|c|}{ Jabatan/Bagian } & $\begin{array}{c}\text { Jumlah Pegawai } \\
\text { yang ada }\end{array}$ \\
\hline Keuangan & 3 \\
\hline Umum & 3 \\
\hline $\begin{array}{l}\text { Pendidikan dan } \\
\text { Kebudayaan }\end{array}$ & 3 \\
\hline $\begin{array}{l}\text { Perekonomian dan } \\
\text { Pembangunan }\end{array}$ & 3 \\
\hline $\begin{array}{l}\text { Ketentraman dan ketertiban } \\
\text { umum }\end{array}$ & 3 \\
\hline Kesejahteraan Sosial & 9 \\
\hline Pemerintahan & 0 \\
\hline Pelayanan & $\mathbf{2 6}$ \\
\hline Jumlah & \\
\hline
\end{tabular}

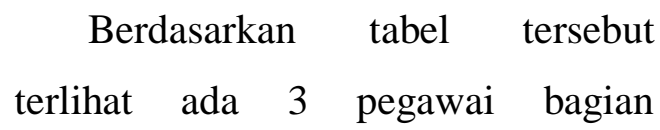

keuangan, 3 pegawai bagian umum, 2 pegawai bagian pendidikan dan kebudayaan, 3 pegawai bagian perekonomian dan pembangunan, 3 pegawai bagian ketentraman dan ketertiban umum, 3 pegawai bagian kesejahteraan sosial, 9 pegawai bagian pemerintahan dan 0 untuk bagian pelayanan. Bagian loket pelayanan umum belum mempunyai pegawai tetap yang bertugas. Kekosongan tersebut diisi oleh pegawai bagian lain dan merangkap tugas pada bagian pelayanan. Pelaksanaan pelayanan publik yang berkualitas memerlukan dukungan Sumber Daya Manusia (SDM), yaitu pegawai atau karyawan yang siap dan handal karena pegawai merupakan pihak yang melakukan pelayanan publik, terutama ketika berhadapan langsung dengan masyarakat, konsumen, dan pelanggan. Pelayanan publik yang berkualitas salah satunya dapat dilihat dari Kualitas SDM yang ada di Instansi pemerintah atau lembaga yang melakukan pelayanan publik. Salah satu faktor penentu lembaga dapat dikatakan berkualitas adalah dengan adanya SDM yang siap dan handal dalam melayani masyarakat sebagai pengguna layanan.

Salah satu faktor utama kesuksesan dalam pelayanan adalah keramahan kepada pengguna layanan yang salah satu contohnya dengan tersenyum dan menyapa, dengan 
senyuman dan sapaan maka pengguna layanan akan merasa bahwa dirinya telah diperhatikan dan dari situ muncul dari dalam hati pengguna layanan bahwa pengguna layanan akan merasa nyaman dengan pelayanan yang diberikan oleh penyedia layanan. Keramahan memang bukan aset, tetapi keramahan adalah kunci sukses untuk penyedia layanan menjalin hubungan yang baik dengan pengguna layanan.

Dalam proses pelayanan publik tidak selalu berjalan sesuai dengan yang diharapkan, masih terdapat faktor-faktor yang menghambat proses pelayanan publik, diantaranya sumber daya pegawai yang masih kurang dan dibuktikan dengan ketiadaan pegawai tetap di seksi pelayanan bagian pelayanan yang pastinya sudah menguasai yang berkaitan dengan proses pelayanan. Pegawai pelayanan kantor pelayanan Kecamatan Karanggeneng saat ini adalah mereka yang bertugas di seksi pemerintahan ada tiga orang dan satu orang lainnya berasal dari seksi-seksi lain di Kecamatan Karanggeneng yang mempunyai tugas untuk bergantian menjaga di bagian pelayanan karena yangmenjaga di bagian pelayanan umum bukan dari bagian pelayanan itu sendiri, maka keahlian yang dimiliki khususnya pegawai dibagian pelayanan belum bisa optimal.
Kegiatan pelayanan merupakan kegiatan yang berhadapan langsung dengan orang lain yaitu pengguna layanan yang membutuhkan pelayanan.Selain sumber daya pegawai faktor penghambat lain adalah sarana dan prasarana seperti ketidakadaan filing cabinet sebagai tempat untuk penyimpanan arsip yang menyebabkan penyimpanan dokumen tidak tertata dengan sebagai mana mestinya yang pada akhirnya menyebabkan pegawai mengalami kesulitan dalam menemukan arsip yang dibutuhkan serta mengganggu kerapian ruang pelayanan. Ketidakrapian ini menyebabkan ketidaknyamanan pengguna layanan ketika melakukan proses pelayanan. Faktor penghambat lain adalah mengenai jangka waktu yang diberikan terkait pembuatan KTP yang tidak sesuai dengan jangka waktu yang ditetapkan karena kurangnya pembuatan bahan dasar KTP. Keterlambatan ini dikarenakan kartu untuk pembuatan KTP sendiri harus menunggu kiriman dari kantor pusat yang membutuhkan waktu tidak sebentar. Itulah faktor utama yang menyebabkan jangka waktu pembuatan KTP tidak sesuai dengan jangka waktu yang seharusnya.

Faktor yang mendorong terwujudnya pelaksanaan yang berkualitas di kantor Kecamatan Karanggeneng adalah penanaman kesadaran melayani masyarakat 
dengan ikhlas sesuai dengan hati nurani. Kesadaran di sini maksudnya bahwa pegawai pelayanan mempunyai suatu tanggung jawab melayani pengguna layanan. Faktor pendukung lain adalah dengan adanya fasilitas yang membantu pegawai dalam melaksanakan tugasnya melayani pengguna layanan yaitu berupa alat bantu komputer dan perangkatnya serta adanya sambungan internet sehingga proses pelayanan dapat berjalan dengan lancar.

Hambatan pelayanan dalam upaya menjaga kualitas pelayanan pada masyarakat di Kantor Kecamatan Karanggeneng Kabupaten Lamongan adalah yang mengurusi bagian pelayanan mengatakan bahwa "pelayanan untuk masyarakat saat ini agak terkendala oleh masalah infrastruktur organisasi seksi pelayanan yang tidak ada. Untuk pegawai pelayanan yang ada sekarang, kami hanya mengambil beberapa orang dari seksi pemerintahan dan lainnya dari semua seksi yang ada di Kecamatan yang mempunyai tugas piket menjaga di Kantor pelayanan bergabung dengan pegawai dari seksi pemerintahan di kantor pelayanan. Namun dalam menjaga di kantor pelayanan, mereka juga harus tetap memprioritaskan pekerjaan tetap mereka di seksinya masing-masing."

\section{KESIMPULAN}

Berdasarkan uraian pada hasil penelitian dan pembahasan, dapat ditarik kesimpulan secara umum sebagai berikut:

1. Kualitas pelayanan publik di Kantor Kecamatan Karanggeneng Kabupaten Lamongan dapat dinilai dari lima dimensi yaitu Tangibel, Reliability, Responsiviness, Assurance, dan Emphaty.

a. Dimensi Tangibel (Bukti Fisik) yang mempunyai indikator penampilan, kenyamanan, kemudahan, dan penggunaan alat bantu sudah diterapkan, namun ada indikator yang belum sepenuhnya di laksanakan yaitu mengenai kenyamanan tempat pelayanan.

b. Dimensi Reliability (Kehandalan) yang mempunyai indikator kecermatan, standar pelayanan yang jelas, kemampuan, dan keahlian sudah diterapkan, namun ada indikator yang belum berjalan sesuai harapan masyarakat yaitu mengenai keahlian pegawai dalam menggunakan alat bantu pelayanan.

c. Dimensi

Responsiviness (Ketanggapan) yang mempunyai indikator merespon, cepat, tepat, cermat, tepat waktu dan merespon keluhan pengguna layanan sudah diterapkan dimensi ini sesuai dengan keinginan masyarakat terbukti karena tidakada keluhan dari pengguna layanan terkait indikator dalam dimensi Responsiviness.

d. Dimensi Assurance (Jaminan) yang mempunyai indikator 
jaminan tepat waktu dan jaminan kepastian biaya sudah diterapkan sesuai dengan keinginan masyarakat. Hal ini terbukti karena tidak ada keluhan dari pengguna layanan terkait indikator dalam dimensi Assurance.

e.Dimensi Emphaty (Empati) yang mempunyai

indikatormendahulukan

kepentingan pengguna layanan, ramah sopan santun, tidak diskriminatif, dan menghargai sudah diterapkan, namun ada indikator yang belum berjalan sesuai harapan masyarakat yaitu mengenai ketidakramahan pegawai layanan dalam melayani pengguna layanan.

2. Faktor penghambat pelaksanaan pelayanan publik di Kantor Kecamatan Karanggeneng Kabupaten Lamongan adalah kurangnya sumber daya pegawai dan masih kurangnya sarana prasarana. Sedangkan faktor pendukungnya adalah semangat yang diberikan pegawai satu sama lain, mengadakan rapat koordinasi atau semacam evaluasi setiap tiga bulan kemudian memberikan penanaman kesadaran melayani masyarakat dengan ikhlas dan sesuai dengan hati nurani. Faktor pendukung yang lain adalah adanya fasilitas berupa alat bantu untuk memudahkan proses pelayanan.

\section{DAFTAR PUSTAKA}

Atep Adya Barata. 2003. Dasar - Dasar Pelayanan Prima. Jakarta : Yudhistira.

Hardiyansyah. 2011. Kualitas Pelayanan Publik. Yogyakarta : Gava Media

Kasmir. 2006. Manajemen Perbankan. Jakarta : Kencana Prenada Media Group Lembaga Administrasi Negara.2004.System Administrasi Negara Kesatuan Republik Indonesia (SANKRI); Dalam landasan dan pedoman pokok penyelenggaraan dan pengembangan system administrasi negara

Moenir H.A.S. 2002. Manajemen Kantor. Jakarta : Yudhistira

Ratminto \& Atik Septi Winarsih. 2007. Manajemen Pelayanan. Yogyakarta : Pustaka Pelajar

Tjiptono, Fandy. 2000. Manajemen Jasa. Yogyakarta : Andi

\section{Peraturan-Peraturan}

Keputusan Menteri Pendayagunaan Aparatur Negara No. 63 tahun 2003 tentang pedoman umum penyelenggaraan pelayanan publik.

Keputusan Menteri Pendayagunaan Aparatur Negara Nomor 63 tahun 2004 Tentang Pedoman Umum Penyusunan Indeks Kepuasan Masyarakat Unit Pelayanan Instansi Pemerintah.

Peraturan Menteri Pendayagunaan Aparatur Negara Dan Reformasi Birokrasi Republik Indonesia Nomor 15 Tahun 2004 tentang Komponen Standar Pelayanan.

Undang-Undang Nomor 25 Tahun 2009 tentang Pelayanan Publik.

Internet

(http://www.merdeka.com/peristiwa/laporanpengaduan-pelayanan-publik-keombudsman-meningkat-350.html) 